\title{
Discovering a Global Perspective
}

\author{
Jennifer Aston and Catherine Bishop
}

\section{IN THE BEGINNING}

Never underestimate the power of a serendipitous 'Google' search. One such query for 'female business ownership' led an Australasian historian (Catherine Bishop) to email a British one (Jennifer Aston) having discovered a common passion for nineteenth-century businesswomen. We realised that we had been following similar paths 12,000 miles apart, uncovering the presence of entrepreneurial women in nineteenth-century Australasia and England. ${ }^{1}$ Yet, even in this, the age of the internet and

We would like to thank Béatrice Craig, Susan Ingalls Lewis, Richard White and Mary A. Yeager for their perceptive and helpful comments on earlier drafts of this chapter.

${ }^{1}$ Catherine Bishop, Minding Her Own Business: Colonial Businesswomen in Sydney, (Sydney: NewSouth, 2015), Catherine Bishop, Women Mean Business: Colonial Businesswomen

J. Aston $(\bowtie)$

Northumbria University, Newcastle Upon Tyne, UK

e-mail: jennifer.aston@northumbria.ac.uk

C. Bishop

Macquarie University, Sydney, NSW, Australia

e-mail: catherine.bishop@mq.edu.au

(C) The Author(s) 2020

J. Aston, C. Bishop (eds.), Female Entrepreneurs in the Long

Nineteenth Century, Palgrave Studies in Economic History, https://doi.org/10.1007/978-3-030-33412-3_1 
transnational history, we had been unaware of each other's existence. We had each operated within historiographical traditions that for the most part denied the existence of respectable businesswomen in this era; a critical century which saw rapid economic change and increasing regulation of business. We were excited, firstly to discover our 'own' entrepreneurial women, and then to discover that they also existed on the other side of the world. Even more important than our discovery of a historiographical soul mate, however, was that it immediately meant that the presence of businesswomen could not be simply explained by England's industrialisation or by Australasia's settler colonial status. These two locations and that email were just the beginning. We began to reach out and make further connections, initially with North American scholars. ${ }^{2}$ We organised a conference panel with Susan Ingalls Lewis, one of the pioneers in US feminist business history, on 'Nineteenth-Century Businesswomen in the Anglophone World'. Our ensuing discussions highlighted the commonalities in laws and customs among Australia, the UK and the United States, and sparked the obvious questions: 'what about the rest of the world?' and 'who else is working on this that we don't know about?'

This led us to reconsider the geographical frames of reference in which our own historical research was undertaken. We knew of North American scholarship, and European studies in the area, but all of these existed within national contexts. ${ }^{3}$ Comparative work was situated within European or, most recently and notably by Béatrice Craig, trans-Atlantic frameworks.

in New Zealand, (Dunedin: Otago University Press, 2019), Jennifer Aston, Female Entrepreneurship in Nineteenth Century England: Engagement in the Urban Economy (London: Palgrave Macmillan, 2016).

${ }^{2}$ Catherine organised a panel at the Canadian Historical Association's annual conference featuring Canadian scholars of English and French-speaking Canada, Peter Baskerville, Bettina Bradbury and Melanie Buddle, as well as Catherine herself. Jennifer, Catherine and Susan Ingalls Lewis presented a panel, 'Nineteenth-Century Businesswomen in the Anglophone World', chaired by Mary Yeager at the Association of Business Historians' Annual Conference in Glasgow in 2017. Catherine was part of two international panels at the 2018 World Economic History Conference in Boston, one on businesswomen spanning the nineteenth and twentieth centuries, including Galina Ulianova, Susanna Martinez Rodriguez, Amada Gregg, Erica Salvaj, Andrea Lluch and chaired by Béatrice Craig.

${ }^{3}$ Susan Ingalls Lewis, Unexceptional Women: Female Proprietors in mid-19th Century Albany New York 1830-1885, (Columbus: Ohio State UP, 2009); Edith Sparks, Capital Intentions: Female Proprietors in San Francisco, (Chapel Hill: University of North Carolina Press, 2006). 
The rest of the globe has not generally featured in the discussion. ${ }^{4}$ Our ambition in this volume is to start the global conversation, to unite historians of businesswomen working on diverse parts of the world, incorporating areas south of the equator and east of the Urals. We want to explore, compare and contrast women's experiences of business, and examine how differing economies, cultures and legal structures affected their approaches, or perhaps excluded them altogether. We also want to investigate how the available sources and historiographical traditions of each place have determined the way that the stories of female entrepreneurs have been told or not told. Naturally, much of the scholarship is found in countries with stronger, longer historiographical traditions, where the history of business, entrepreneurship and gender has entered the accepted historical canon. Nevertheless, this volume breaks new ground in its geographical coverage, including chapters from Western Europe (France, Spain, and UK), Eastern Europe (Russia, Turkey), North America (Canada, the United States), Central and South America (Mexico, Brazil), Asia (China, Japan), Africa (Angola, South Africa) and Australasia (Australia, New Zealand). Of course, this mapping is far from complete and we eagerly anticipate the continuation of the project as the conversation widens. This is not a book about global entrepreneurs, although many of the businesswomen in the following pages were transnational migrants. ${ }^{5}$ Their businesses, however, were predominantly conducted locally and therefore national history remains the dominant framework. Most chapters address separate national contexts but what they do not do is assume national exceptionalism. Instead, our global perspective highlights similarities, illuminates differences and encourages economic, social, business and gender historians to ask new questions.

${ }^{4}$ Béatrice Craig, Women and Business since 1500: Invisible Presences in Europe and North America? (NY: Palgrave Macmillan, 2016). Two collections, while primarily focused on Britain, Europe and North America did spread the net slightly wider. David Green, Alistair Owens, Josephine Maltby and Janette Rutterford (eds), Men, Women and Money, Perspectives on Gender, Wealth and Investment 1850-1930, (Oxford: OUP, 2011), included a chapter on South Australia; Anne Laurence, Josephine Maltby and Janette Rutterford (eds), Women and their Money 1700-1950: Essays on Women and Finance, (Abingdon: Routledge, 2009), included a chapter on Japan.

${ }^{5}$ For a discussion of business, gender and mobility see Catherine Bishop, 'Women on the Move: Gender, Money-making and Mobility in Mid-Nineteenth Century Australasia', History Australia 11, no. 2 (2014): pp. 38-59. 
The female entrepreneurs who populate the following pages existed in multiple geographical areas with uneven economic development. Some economies were highly industrialised, others less so. Some national and local economies were hostage to the priorities of distant imperial governments, while for others, industrialisation was not yet (and in a few cases is still not) an inevitable conclusion. The focus of much existing scholarship on nineteenth-century female entrepreneurship is on women in towns and cities, indicative perhaps of the sources available though perhaps too on the false assumption that farmers were not entrepreneurial. ${ }^{6}$ Therefore, in addition to extending the geographical scope of the field, we also seek to include rural literatures and consider women's independent moneymaking activities across economies and industries, as well as borders, for the first time. Frontier societies, long-established European cities and new company towns all appear in these chapters and, while many of the businesswomen examined were urban-based, others were not. The laundresses of Mexico City, the merchants of Paris and the retailers of central and suburban Moscow sit alongside African farmers of the Eastern Cape, agricultural producers in England, the first Western settlers in British Colombia and New Zealand, and the pirates of the South China Sea.

\section{DeFinitions}

Business exists within local, national and international frameworks of religion, custom, government and personal relationships. We have deliberately employed very broad definitions of business and entrepreneurship to capture as many manifestations of female entrepreneurship as possible. The following chapters define businesswomen as women who were making money and business decisions on their own account, either as sole traders, employers, artisans, or by dealing in property or making financial investments. They were not waged workers or salaried employees following orders. They could be running their enterprises on a micro scale, as owners of international companies, or in the liminal space of the 'grey market' between legal enterprise and illegal activity. Their businesses could be full-time, part-time or seasonal and they may have had multiple enterprises at any one time or sequentially. Their businesses could last just a few

\footnotetext{
${ }^{6}$ Adam Ward Rome argued for farmers to be considered business people in 'American Farmers as Entrepreneurs, 1870-1900', Agricultural History 56, no. 1 (1982): pp. 37-49, and articulates the debate.
} 
months or several decades, or survive over multiple generations. We include women who were in partnership, formally or informally, with husbands or others. In particular, we acknowledge that many wives usually described in the records as 'assisting in their husbands' businesses' (or not described in the records at all) were frequently essential business partners and considered as such by their spouses, customers and themselves; they deserve this acknowledgement by historians.

Some definitions of-or assumptions about-entrepreneurship privilege expansion and innovation. ${ }^{7}$ We prefer a more expansive definition of entrepreneur: someone who identifies opportunities for business, takes risks (however small they might seem), assumes responsibility for decisions and seeks to make money. Thus, a laundress who recognises a market for clean laundry, takes the risk of establishing herself in business, negotiates credit, is responsible if she fails to deliver clean laundry on time and who wants to make enough money to support herself and any dependants, is as entitled to the epithet 'entrepreneur' as Henry Ford or Andrew Carnegie: she perhaps has more at stake. Entrepreneurship can take many forms, from a desire for almost limitless expansion to piecemeal work that provides sufficiency, and everything in-between. High-risk ventures with significant financial investments and potentially colossal returns have tended to dominate the literature surrounding entrepreneurship and business ownership and in the popular imagination, but they are hardly representative. More typical are the thousands of enterprises formed at kitchen tables that provided varying levels of income and security to their owners and then faded away, almost-but not quite-into obscurity.

The question of how we define success is equally important. Business success is often evaluated solely in terms of growth and maximising profit. Such a definition devalues those businesspeople-men and women-who did not expand their enterprises to become international conglomerates, but instead persevered in building their businesses sufficiently to create a living for their families and then were satisfied. While some businesspeople may have wanted to expand, others had no such intentions. Another

${ }^{7}$ Joseph A. Schumpeter, Capitalism, Socialism and Democracy, (London: George Allen and Unwin, 1976); Joe Carlin, A Brief History of Entrepreneurship: The Pioneers, Profiteers and Racketeers Who Shaped Our World, (New York: Columbia University Press, 2016); Frank H. Knight, Risk Uncertainty and Profit, (Boston and New York: Houghton Mifflen, 1921): Mark Casson, 'Entrepreneurship': www.econlib.org/library/Encl/Entrepreneurship.html; Ian Hunter, Age of Enterprise: Rediscovering the New Zealand Entrepreneur 1880-1910, (Auckland, Auckland University Press, 2007), p. 18. 
equally flawed measure of success is longevity. A business that closes its doors after two years because it has fulfilled its owner's modest aims must be counted a success, though some would count it a failure. Rather than judging business success by externally applied, value-laden judgments which assume that bigger is always better or a short-lived business must be a failure, we have sought to evaluate a business's success and/or failure by assessing whether or not it fulfilled its owner's aims. Finding direct evidence for the motivations of business owners is, of course, very difficult, which helps explain why many observers fall back on the easily quantifiable metrics of growth and longevity. Examining female entrepreneurship across the long nineteenth century with these broader and more appropriate definitions allows us to understand the historic importance of these women's activities and make valuable comparisons between different economic and political structures. Traditional economic histories that defined business entities as abstractions unconnected to the lived experience of the people involved have tended to ignore, downplay or overlook the contribution of many ordinary people to economic life. In particular, from our perspective, they have overlooked the contribution of women to both the family and to regional, national and international economies. ${ }^{8}$

The idea of a 'long' nineteenth century-from roughly the 1750 s to the 1920s - has its roots in the study of the 'big' themes of industrialisation, globalisation and modernisation in Anglophone historiography. This long-term approach allows the origins of these developments to be traced and their impact considered. With research spanning from the late eighteenth to the early twentieth century, the chapters in this volume encompass the long nineteenth century in its fullest form. This book connects some of the multiple streams of research now being carried out, unevenly, piece by piece, area by area, century by century, drawing out commonalities and highlighting differences. Western studies of nineteenth-century women's histories tend to focus on the tensions between gender and industrialisation in the first half of the century, or on the political and professional awakening of women in the closing decades, with experiences often viewed and analysed through the lens of social class. ${ }^{9}$ We are,

\footnotetext{
${ }^{8}$ Mary A. Yeager, 'Reframing Business Realities: A Look back into the Future of American Business History', Travail, Genve et Sociétés 1, no. 3 (2005): pp. 95-113.

${ }^{9}$ Jane Rendall, Women in an Industrializing Society: England 1750-1880, (Blackwell: Oxford, 1990); Jane Purvis (ed.), Women's History: Britain 1850-1945, An Introduction, (Routledge: London, 2002 edn); Susie Steinbach, Women in England 1760-1914: A Social History, (Weidenfeld and Nicolson: London, 2004).
} 
however, acutely aware that women's experiences were not homogenous. Ethnicity, religion, race, marital status and economic position all shaped the privileges and disadvantages that women experienced. Gender inequalities were particularly exacerbated for Indigenous women within colonial societies, and the many women who were enslaved for a large portion of the nineteenth century and continued to experience significant social prejudice and economic disadvantage even after abolition had supposedly been enacted. Our cover image shows Jean-Baptiste Carpeaux's Fontaine de l'Observatoire (1872), which depicts four women, Africa, Europe, the Americas and Asia, holding up the earth. The broken chain encircling the ankle of 'Africa' was a contemporary anti-slavery comment by the artist but can also, perhaps, be viewed as a representation of how women around the world found ways to break free of the various shackles that limited their activities. The chapters in this volume therefore represent a rare opportunity to examine women from diverse backgrounds with a shared experience of business across a century that saw dramatic social, political and economic change.

\section{Literature}

In seeking a global perspective, this volume engages with numerous national and regional historiographies, which are explored in detail by authors in their individual chapters. Nevertheless, we have discovered some general trends worth noting here.

In the past 50 years, feminist, social and post-colonial historians have widened our understanding of the past, moving far beyond histories written by and about white men in privileged positions. By adding the experiences of women, working-class and non-white, non-European peoples to the narrative, scholars have not only enlarged the scope of history, but also changed its focus. Initially feminist historians were pointing out that women 'were there too', participating in politics and in the economy despite the obstacles, but it soon became clear that a broader approach was necessary. Historians wanted to explain the inequalities that women throughout the world faced, including (but not limited to) persisting legal, cultural and economic discrimination, limited access to education, gender pay gaps, a lack of women on company boards and in corporate management, and, at worst, endemic physical and psychological abuse. This, along with the historiographical turn towards history-from-below, 
made workers more attractive than employers as historical subjects. Feminist historians also tackled head-on the idea that women's lives were less important than men's in shaping local, national and international histories. While many uncovered and celebrated women's contribution to traditionally male-dominated fields, others, particularly after Joan Scott's 1986 intervention, recognising gender as 'a useful category of historical analysis', emphasised the economic and social importance of women's roles as wives and mothers, as household managers and in charitable and community works. ${ }^{10}$ As Australian historian, Marilyn Lake wrote in 1996:

In the old days men used to say that women weren't in history books because we hadn't done anything. In response to this, the standard feminist riposte was to insist that 'we were there too'. But, I want to suggest, given half a chance, women in the past would retort, 'No, we were somewhere else' - we were in our families, in our bodies, in our self-sacrifice, in our emotions, in our communities, in our women's friendships, in our relationships with the country and with people. ${ }^{11}$

This strand of feminist history demonstrated that women's experiences were just as important in national histories as men's. However, the focus on history from below and on women being 'somewhere else' unintentionally obscured the sorts of female business activities with which this book is concerned. It entrenched the idea, so persuasively argued by Leonore Davidoff and Catherine Hall, that women and men operated in 'separate spheres', particularly in the nineteenth century. ${ }^{12}$ Men had

${ }^{10}$ Joan W. Scott, 'Gender: A Useful Category of Historical Analysis', The American Historical Review 91, no. 5 (Dec. 1986): pp. 1053-75; See also Jill Julius Matthews, 'Feminist History', Labour History 50, (May 1986): pp. 147-53.

${ }^{11}$ Marilyn Lake, 'Rewriting Australia: Rewriting Women', Island, 68: pp. 96-104, p. 96.

${ }^{12}$ In the British context the culture of domesticity was most famously described by Leonore Davidoff and Catherine Hall in Family Fortunes: Men and Women of the English Middle Class, 1780-1850, Rev. ed. (London: New York: Routledge, 2002); In Australia, Beverley Kingston (A History of New South Wales, (Cambridge: Cambridge University Press, 2006), p. 59, and My Wife, My Daughter and Poor Mary Ann: Women and Work in Australia, (Melbourne, Thomas Nelson, 1975)) epitomised the approach of many other historians such as Katrina Alford (Production or Reproduction?: An Economic History of Women in Australia, 1788-1850, (Melbourne: Oxford University Press, 1984)) and Rita Farrell ('Women and Citizenship in Colonial Australia', in Patricia Crawford and Philippa Maddern (eds), Women as Australian Citizens: Underlying Histories, (Melbourne: Melbourne University Press, 2001): Ch. 5) and Penny Russell, A Wish of Distinction: Colonial Gentility and Femininity, (Melbourne, 
responsibility for the public sphere of politics and business, while women belonged in-or were relegated to-the private sphere of the home, bearing and raising children. Men were entrepreneurial, women self-sacrificing. In recent years, historians of women have comprehensively challenged the idea that the nineteenth-century world was rigidly divided into separate spheres. While there were legal and educational restrictions on women's participation in many activities, as well as much public rhetoric, women could move outside purely domestic roles. As early as 1984, Jill Julius Matthews reminded us that

analysts of working women tend to look in the wrong place ... we have sought to find women where we have already found men ... we have accepted the gender division of labour, but only after we have accepted the masculine perception of the world divided easily into work and home. ${ }^{13}$

In 1993, British historian Amanda Vickery drew attention to the chronological inconsistencies of the separate spheres theory more broadly, but it continues to pervade not just historiographies of the nineteenth century, but also the more general understanding of what it meant to be female before the late twentieth century. ${ }^{14}$ The result of this persistence has been that, as Béatrice Craig argued in 2015, scholars have been 'disinclined to look for [businesswomen]: one does not search for what one believes does not exist'. ${ }^{15}$

Melbourne University Press, 1994). In New Zealand Raewyn Dalziel's work was foundational in establishing the idea of the 'colonial helpmeet', useful but contained, in 'The Colonial Helpmeet: Women's Role and the Vote in Nineteenth-Century New Zealand', New Zealand Journal of History 11, (1977): pp. 112-23; In North America, Nancy Cott's The Bonds of Womanhood: Women's Sphere in New England, 1780-1835, (New Haven: Yale University Press, 1977) was significant and in France, Bonnie Smith, Ladies of the Leisure Class, The Bourgeoisie of Northern France in the Nineteenth Century, (Princeton: Princeton University Press, 1981) remains influential.

${ }^{13}$ Jill Julius Matthews, 'Deconstructing the Masculine Universe: The Case of Women's Work', in Women and Labour Publications Collective (ed.), All Her Labours One: Working It Out, (Sydney: Hale and Iremonger, 1984): pp. 11-23, p. 15. Similarly, Paula J. Byrne, 'Economy and Free Women in Colonial New South Wales', Australian Feminist Studies 11, no. 23 (1996): pp. 89-97.

${ }^{14}$ Amanda Vickery, 'Golden Age to Separate Spheres? A Review of the Categories and Chronology of English Women in History', The Historical Journal 36, no. 2, (June 1993): pp. 383-414.

${ }^{15}$ Craig, Women and Business, p. 4. 
We must also remember that early ground-breaking works in the field of women's history were writing from a markedly different perspective. Writing in the 1930s, historian Ivy Pinchbeck concluded that the industrial revolution fundamentally changed women's lives with the genesis of what she called the 'modern' idea that married women made an adequate and valuable contribution to society through caring for the home and children. ${ }^{16}$ Similarly, female historians writing in the 1970s and 1980s were battling such ideas on multiple fronts, fighting for equality in their own personal and professional lives while simultaneously trying to restore the female experience to the broader historical narrative. Historians are as much a product of their times as their subjects.

Therefore, when feminist historians began to turn their attention to business history in the 1990s, they too had to challenge what had become conventional wisdom. Historians in North America were among the first, including Peter Baskerville and Sylvia Van Kirk in Canada and Wendy Gamber, Angel Kwolek-Folland, Susan Ingalls Lewis, Edith Sparks and Mary A. Yeager in the United States. ${ }^{17}$ In Britain, it was not until Hannah Barker, Nicola Phillips and Alison Kay published their research in 2006 and 2009 that the reinterpretation of women's engagement in business there began in earnest. Simultaneously, economic and business historians including Robert Beachy, David R. Green, Pat Hudson, Jane Humphries, Anne Laurence, Josephine Maltby, Alistair Owens and Janette Rutterford were reassessing the role of women in both industrialisation and finance. ${ }^{18}$

${ }^{16}$ Ivy Pinchbeck, Women Workers and the Industrial Revolution, 1750-1850, 3rd ed. (London: Virago, 1981).

${ }^{17}$ Peter Baskerville, "'She Has Already Hinted at Board": Enterprising Urban Women in British Columbia 1863-1896', Histoire sociale- Social History 26, No. 52 (1993): pp. 205-227; Sylvia Van Kirk, Many Tender Ties: Women in Fur-Trade Society, 1670-1870, (University of Oklahoma Press, 1983); Wendy Gamber, 'A Gendered Enterprise: Placing Nineteenth-Century Businesswomen in History', Business History Review 72, (Summer 1998): pp. 188-217; Susan Ingalls Lewis, 'Female Entrepreneurs in Albany, 1840-1885', Business and Economic History 21, (1992): pp. 65-73; Edith Sparks, 'Married Women and Economic Choice: Explaining Why Women Started Businesses in San Francisco between 1890 and 1930', Business and Economic History 28, no. 2 (Winter 1999): pp. 287-300; Mary A. Yeager (ed.) Women in Business, 3 vols, (Cheltenham: Edward Elgar Publishing; 1999).

${ }^{18}$ Hannah Barker, The Business of Women: Female Enterprise and Urban Development in Northern England 1760-1830, (Oxford: Oxford University Press, 2005); Nicola Phillips, Women in Business, 1700-1850, (Woodbridge: Boydell and Brewer, 2006); Alison C. Kay, The Foundations of Female Entrepreneurship: Enterprise, Home and Household in London, $c$. 1800-1870, (London: Routledge, 2009); Robert Beachy, Béatrice Craig and Alastair Owens 
Historians writing in English on nineteenth-century female business ownership in other European countries include Tom Ericsson for Sweden, Irene Bandauer-Schöffmann for Austria, Barbara Curli and Maura Palazzi for Italy. However, there are also several non-English-language articles and monographs that have shaped national historiographies, although they have had a more limited influence on the international conversation, which is still conducted primarily in English. With some notable exceptions, such as South American historian Muriel Nazzari in 1995, historians of other parts of the world have been slower to contribute to this strand of revisionist historiography, from either a business or feminist history perspective. ${ }^{19}$ It was not until 15 years after the publication of Angel Kwolek-Folland's Incorporating Women: A History of Women and Business in the United States, that Catherine Bishop undertook the first full-length studies of businesswomen in nineteenth-century Australia and New Zealand. In Africa, Douglas Wheeler's 1996 examination of a midnineteenth-century female Luso-African merchant in Angola was a precursor to more sustained investigations by Mariana Cantido, Selma Pantoja and Vanessa Oliveira a decade later. ${ }^{20}$ South African historians

(eds), Women, Business, and Finance in Nineteenth-Century Europe: Rethinking Separate Spheres, (Oxford: Berg 2006) Green et al. (eds) Men, Women and Money; Jane Humphries, " "Lurking in the Wings...": Women in the Historiography of the Industrial Revolution', Business and Economic History 20, (1991): pp. 32-44; Laurence et al. (eds), Women and Their Money.

${ }^{19}$ Barbara Curli, 'Women Entrepreneurs and Italian Industrialization: Conjectures and Avenues for Research', Enterprise and Society (2002), 3, pp. 634-656; Irene BandauerSchöffmann, 'Businesswomen in Austria', in Beachy, Craig and Owens (eds), Women, Business and Finance in Nineteenth Century Europe, Rethinking Separate Spheres (London: Berg, 2006): pp. 110-124; Tom Ericsson, 'Women, family, and small business in late nineteenth century Sweden', The History of the Family (2001), 6:2, pp. 225-239; Nicola Foote, 'Rethinking Race, Gender and Citizenship: Black West Indian Women on the Atlantic Coast of Costa Rica, c.1920-1940', Bulletin of Latin American Research 23, no. 2 (April 2004), pp. 198-21; Muriel Nazzari, 'Widows as Obstacles to Business: British Objections to Brazilian Marriage and Inheritance Laws', Comparative Studies in Society and History 37, no. 4, (1995): pp. 781-802; Maura Palazzi, 'Economic autonomy and male authority: Female merchants in modern Italy', Journal of Modern Italian Studies (2002) 7, pp. 17-36.

${ }^{20}$ Douglas L. Wheeler, 'An Angolan Woman of Means: D. Ana Joaquina dos Santos e Silva, Mid-Nineteenth Century Luso-African Merchant-Capitalist of Luanda', Santa Bárbara Portuguese Studies 3, (1996): pp. 284-97; Mariana Candido, 'Aguida Gonçalves da Silva, une dona à Benguela à la fin du XVIIIe siécle', Brésil(s): Sciences bumaines et sociales 1 , (2012): pp. 33-54; Mariana Candido, 'Strategies for Social Mobility: Liaisons between Foreign Men and Slave Women in Benguela, c. 1770-1850', in Gwyn Campbell and Elizabeth Elbourne (eds), Sex, Power and Slavery: The Dynamics of Carnal Relations under Enslavement, (Athens: Ohio University Press, 2014): pp. 272-288; Selma Pantoja, 'Women's 
have not previously approached the topic of nineteenth-century women in business, with the chapters in this volume by Sean Redding and Grietjie Verhoef representing the first forays into the field. As Verhoef points out, this perhaps results from different historiographical priorities in Africa, where race, slavery and colonialism have rightly loomed larger. ${ }^{21}$ Similarly, as Seven Ağır acknowledges, the study of female business owners is a relatively underexplored area of the Turkish historiography. ${ }^{22}$ With the exception of women as brothel keepers, there are only tantalising glimpses of female entrepreneurship in nineteenth-century China, although it must be noted that the Chinese diaspora has received greater attention. ${ }^{23} \mathrm{It}$ might be that 'legitimate' Chinese female business owners were not there to find, but this then raises important questions of what caused them to leave - or not enter - the marketplace, and what they were doing instead. In her examination of Chinese female brothel keepers in Hong Kong for example, Elizabeth Sinn noted that 'since few women in nineteenth-century Chinese society had the opportunity to operate businesses, brothel keeping in Hong Kong was one of the first arenas where they could realize and develop their entrepreneurial skills' ${ }^{24}$ Alternatively, it could be that cultural forces meant that they became less visible participants within family businesses-still there, but not in plain sight. Business historian Chi Cheung Choi has explored the significance of maternal kinship ties in Chinese business in the period, in similar fashion to Mary Louise Nagata's examination of family firms in nineteenth-century Kyoto in this volume,

Work in the Fairs and Markets of Luanda', in Clara Sarmento (ed.), Women in the Portuguese Colonial Empire: The Theatre of Shadows, (Newcastle upon Tyne: Cambridge Scholars Publishing, 2008): pp. 81-94; Vanessa S. Oliveira, 'The Gendered Dimension of Trade: Female Traders in Nineteenth Century Luanda', Portuguese Studies Review 23, no. 2 (2015): pp. 93-121.

${ }^{21}$ Verhoef, Chap. 3 in this volume. We are grateful to Amy Rommerspacher for her assistance in investigating South African historiography.

${ }^{22}$ A ğır, Chap. 17 in this volume.

${ }^{23}$ Gregor Benton, Hong Liu and Huimei Zhang (eds), Qiaopi Trade and Transnational Networks in the Chinese Diaspora, (Abingdon: Routledge, 2018); Natalie Fong, "Chinese Capitalists" and the Cultivation of Trade: Australian-Chinese Transnational Businesses and Practices, 1880s-1940s', conference paper, Australian Historical Association conference 2019.

${ }^{24}$ Elizabeth Sinn, 'Women at Work: Chinese Brothel Keepers in 19th Century Hong Kong', The Journal of Women's History 19, no. 3 (2007): pp. 87-111. 
and has likewise stressed the importance of both maternal and paternal kinship ties to the success and longevity of family firms. ${ }^{25}$

There was a high level of prescriptive and proscriptive rhetoric about women and domesticity circulating the nineteenth-century globe, but this should not be read as reflecting how women behaved. We argue it could well suggest women were not behaving as they should. Why else would it have been necessary to reinforce the idea so insistently that women should be contained? We certainly do not deny that the rhetoric of female domesticity was found all over the world, particularly in places colonised by Europeans. Some late-nineteenth-century women even espoused 'professionalised domesticity', arguing that middle-class domesticity required a professional approach, which took just as much effort as employment or business ownership. ${ }^{26}$ However, as the following chapters show, the embodiment of the ideal domestic helpmeet wife differed from place to place, between classes and across time. The ideal of domesticity was predominantly aimed at white middle-class women, but the leisured lives of these women relied upon the visible (and invisible) hard work of an army of working-class and non-white women. Catherine Bishop identifies variations in New Zealand where the mid-century role of a 'useful wife' or 'colonial helpmeet' could respectably encompass business activity for middle-class women of both white European and Māori descent. ${ }^{27}$ Jennifer Aston's work on women in late-nineteenth-century Britain shows that successful middle-class businesswomen engaged in what prevailing rhetoric would have termed genteel and respectable middle-class female practices as well as the public civic roles that characterised successful middle-class businessmen. This indicates female business owners were included in polite society rather than being excluded from it merely because they engaged in trade. ${ }^{28}$ On the other hand, chapters by Kari Zimmerman on Brazil, and Carmen María Hernández-Nicolás and Susana MartínezRodríguez on Spain, point to the ideology of domesticity being stronger in particular societies, notably those in which the Catholic church dominated, requiring some adept manipulation by some women on the one hand, although providing opportunities in family businesses on the other.

\footnotetext{
${ }^{25}$ Chi Cheung Choi, 'Kinship and Business: paternal and maternal kin in the Chaozhou Chinese family firms', Business History 40, (1998): pp. 26-49.

${ }^{26}$ See the lives of Catharine Beecher and Ellen Swallow Richards in North America, Harriet Wicken and Amy Schauer in Australia, and Isabella Beeton in Great Britain.

${ }^{27}$ See Bishop, Chap. 7 in this volume.

${ }^{28}$ Aston, Female Entrepreneurship, Chaps. 5 and 6.
} 
Business historians are increasingly challenging the stereotype of heroic, alpha-male, Schumpeterian entrepreneurs of the nineteenth century, painting them instead as more carefully calculating and imaginative risk takers and inadvertently becoming more gender inclusive. This is occurring alongside the growing number of feminist historians who have, as noted above, unequivocally positioned women as central figures in almost all aspects of nineteenth-century economic life, working both independently and in partnerships with family and others, in small and large scale manufacturing processes, retailing operations, farming and elite estate management. ${ }^{29}$ Although sporadic and uneven, this revisionist

${ }^{29}$ Barker, The Business of Women; Peter Baskerville, A Silent Revolution?: Gender and Wealth in English Canada, 1860-1930, (Montreal, McGill-Queen's University Press, 2008); Bettina Bradbury, From Wife to Widow: Lives, Laws and Politics in Nineteenth-Century Montreal, (Vancouver: University of British Columbia Press, 2011); Melanie Buddle The Business Of Women: Marriage, Family and Entrepreneurship in British Columbia 1901-51 (Vancouver: University of British Columbia Press, 2011); Wendy Gamber, The Boarding House in Nineteenth-Century America, (Baltimore: Johns Hopkins University Press, 2007); Wendy Gamber, The Female Economy: The Millinery and Dressmaking Trades, 1860-1930, (Urbana: University of Illinois Press, 1997); Eleanor Gordon and Gwyneth Nair, 'The Economic Role of Middle-Class Women in Victorian Glasgow', Women's History Review 9, no. 4 (2000): pp. 791-814; David Green and Alistair Owens, 'Gentlewomanly Capitalism? Spinsters, Widows, and Wealth Holding in England and Wales C. 1800-1860', Economic History Review 3 (2003): pp. 510-36; Beth Harris (ed.), Famine and Fashion: Needlewomen in the Nineteenth Century, (Aldershot and Burlington: Ashgate, 2005); Kay, Foundations; Angel Kwolek-Folland, Engendering Business: Men and Women in the Corporate Office 1870-1930, (Baltimore: John Hopkins University Press, 1994); Angel Kwolek-Folland, Incorporating Women: A History of Women and Business in the United States, (NY: Palgrave Macmillan, 1998); Lewis, Unexceptional Women; Laurence et al. (eds), Women and Their Money 1700-1950; Briony McDonagh, Elite Women and the Agricultural Landscape, 1700-1830, (Abingdon: Routledge, 2017); Lucy E. Murphy, 'Business Ladies: Midwestern Women and Enterprise, 1850-1880', Journal of Women's History 3, no. 1 (1991): pp. 65-89; Oliveira, 'The Gendered Dimension of Trade; Phillips, Women in Business; Evan Roberts, 'Her Real Sphere? Married Women's Labor Force Participation in the United States, 1860-1940', (PhD thesis, University of Minnesota, 2007); Pamela Sharpe, The Nineteenth Century Businesswoman in the British Isles: Work Culture, Adaptation and the Lace Trade, (Nedlands, W.A.: Centre for Women and Business, Graduate School of Management, University of Western Australia, 2003); Sparks, Capital Intentions; Glenda Strachan and Lindy Henderson, 'Assumed but Rarely Documented: Women's Entrepreneurial Activities in Late Nineteenth Century Australia', Paper presented at the 'The Past is Before Us' conference, Sydney 2005; Glenda Strachan and Lindy Henderson, 'Surviving Widowhood: Life Alone in Rural Australia in the Second Half of the Nineteenth Century', Continuity and Change 23, no. 3 (2008): pp. 487-508; Galina Ulianova, Female Entrepreneurs in NineteenthCentury Russia, (London: Taylor and Francis, 2009); Claire Wright, Beyond the Ladies Lounge: Australia's Female Publicans, (Melbourne: Melbourne University Press, 2003); 
literature demonstrates that businesswomen were consistently and persistently present in almost every marketplace and dominant in a few. These findings for the nineteenth century continue the story of the eighteenth century, where women's presence in business has been much more readily accepted, in part due to its long-established portrayal as a 'golden age' for women, and foreshadow women's involvement in twentieth-century finance and business corporations. ${ }^{30}$

\section{Sources: Old AND New}

The feminist revolution in historical interpretations of nineteenth-century business owes a great debt to the advent of digital archives, which have made new material available and manipulable to scholars all over the world. Finding women's stories in historical sources is not-and never has been-straightforward, but has become easier with searchable digitised archives and catalogues, along with the corresponding technological advancements in the use of big data. ${ }^{31}$ Historians have been inspired to go back to the archives, either making new discoveries and questioning conventional wisdom, or re-analysing sources to make new comparisons and draw fresh conclusions. The contributors to this volume have taken up the challenge of ignoring the white noise of domesticity and looking for women of enterprise rather than assuming their absence.

Yeager (ed.), Women in Business; Brian Young, 'Getting around Legal Incapacity: The Legal Status of Married Women in Trade in Mid-Nineteenth-Century Lower Canada' in Peter Baskerville (ed.), Canadian Papers in Business History, (Victoria, British Columbia: Public History Group University of Victoria, 1989), pp. 1-16; Kari Zimmerman “"As Pertaining to the Female Sex": The Legal and Social Norms of Female Entrepreneurship in NineteenthCentury Rio de Janeiro, Brazil', Hispanic American Historical Review 96, no. 1 (2016): pp. 39-72.

${ }^{30}$ Vickery, 'From Golden Age to Separate Spheres'; Margaret Hunt, The Middling Sort: Commerce, Gender, and the Family in England, 1680-1780, (Berkeley: University of California Press, 1996); Deborah Simonton and Anne Montenach (eds), Female Agency in the Urban Economy: Gender in European Towns, 1640-1830, (New York: Routledge, 2013); Maria Ågren, 'Making Her Turn Around: the Verb-Oriented Method, the Two-Supporter Model, and the Focus on Practice', Early Modern Women: An Interdisciplinary Journal 13, no. 1 (2018): pp. 144-152; Jane Whittle, 'Enterprising Widows and Active Wives: Women's Unpaid Work in the Household Economy of Early Modern England', History of the Family 19, no. 3 (2014): pp. 283-300.

${ }^{31}$ Catherine Bishop, 'The Serendipity of Connectivity: Piecing Together Women's Lives in the Digital Archive', Women's History Review 26, no. 5 (2017): pp. 766-780. 
Nevertheless, we are often still 'reading against the grain' to capture the surviving fragments of women's lives and to understand their significance to the bigger narrative of economic history. Sometimes this has involved focusing on a single case study, such as in Alisha M. Cromwell's investigation of the complex relationship between elite and enslaved women in the southern US marketplace. Others have compared and contrasted several case studies, such as in Blake Singley's chapter on Australian cookbook writers, Vanessa Oliveira's study of Luso women in Angola and C. Nathan Kwan's discussion of women's roles in the grey economies of Chinese piracy. Catherine Bishop, Melanie Buddle, Béatrice Craig and Susan Ingalls Lewis have knitted together strands from multiple sources to shed light on businesswomen in Australasia, Canada, Paris and the United States, respectively. Combining sources such as official records, account books and contemporary fictional accounts can, as Marie Francois shows in her chapter on Mexican laundresses, paint an evocative picture of the reality of their daily lives. Kari Zimmerman has used Brazilian patent records to understand one expression of female entrepreneurship and more unusually, Sean Redding uses Cape Colony witchcraft cases to provide insight into attitudes toward African women farmers.

With the development of the digital archive has come the possibility of using bigger datasets, enabling these rich micro-histories to be understood within a broader context. One of the most exciting new datasets is the Integrated Census Microdata (I-CeM), utilised here by Carry van Lieshout, Harry Smith and Robert J. Bennett to track female entrepreneurship in England across time, providing both new findings and confirming trends of female business ownership that historians had observed in other sources. Other chapters in this volume also use larger datasets, including the annual population surveys of thirty urban districts in Kyoto, (Mary Louise Nagata), R.G. Dun \& Co. Credit Reports in the United States, (Susan Ingalls Lewis) and the Book of Firms (Libro de Sociedades) in Spain (Carmen Hernandez-Nicolas and Susana Martínez-Rodríguez). Grietjie Verhoef and Seven Ağır have both used similar company records to investigate patterns of female shareholding and company directorship in the Cape Colony and Turkey, respectively. This volume's combination of big history and micro-history shows that there are multiple and imaginative ways to uncover evidence about female enterprise. Significantly, each of these approaches reveals more information about women's activities as business owners, showing the strength of utilising broad definitions and methodologies. 


\section{Sex MatTers}

Having found that businesswomen 'were there too', we need to understand what that meant and why it is important. Adding female entrepreneurs changes the narrative of economic history and bringing multiple studies together allows us to identify common themes as well as important differences. The recent scholarship is by no means homogenous, and neither are the chapters in this volume. A number of important questions emerge in the following chapters: did women do business differently from men? Did different types of economies and societies create different opportunities (or make it more or less essential) for women to enter and succeed in business? What were the gendered experiences of women in business? Did they cluster in certain trades and, if so, how do we interpret that?

In this volume, we turn our attention more fully to how women did business. Board of Trade records from late-nineteenth-century England and Wales, for example, show that men and women operated firms of similar size, engaged in similar levels of risk-taking and enjoyed similar levels of success. Indeed, if we take into account the extra responsibilities many women had as wives and mothers, then there is a good case to argue that female business owners in late-nineteenth-century Britain were actually more successful than their male counterparts. ${ }^{32}$ Contributors to this volume show that businesswomen in Australasia, Paris and the United States shared similar experiences. English trade directory data also suggest that in multigenerational firms, women were in charge for longer than the male family members from whom they inherited the firm. ${ }^{33}$ The importance of women in the transfer of multigenerational firms is also apparent beyond the UK, albeit with variations, as far afield as Spain, Japan and New Zealand, as chapters in this volume demonstrate.

The motivations of individual business owners are difficult to ascertain, and this is true regardless of whether the owner is male or female, but there is little evidence that women were innately less entrepreneurial than men or that they conducted their businesses in any less 'business-like' a manner. The fundamental difference between male and female business owners seems to be not so much in their entrepreneurial ambition, or in

${ }^{32}$ Jennifer Aston and Paolo Di Martino, 'Risk, success, and failure: female entrepreneurship in late Victorian and Edwardian England', Economic History Review 70, no. 3 (August 2013): pp. 837-58.

${ }^{33}$ Aston, Female Entrepreneurship, p. 111. 
their business abilities, but in the gendered external forces affecting their personal and professional lives. It seems to us that the cult of domesticity and the notion of separate spheres have had a far greater impact on the minds of later historians than they ever did on the lived experience of most nineteenth-century women. Nevertheless, there were many constraints placed on women that were not placed on men, particularly in law. Some of the most striking geographical differences revealed by this volume are in the legal structures that restricted or promoted women's business activities, particularly in laws regarding married women's property rights and inheritance practices. The influence of individual colonial regimes is starkly apparent, with continental European laws markedly different from those of the British Empire. Married women in a variety of jurisdictions were subject to specific legal constraints in property and business ownership, though they often found creative ways around the practicalities of trading, including securing credit and bankruptcy. ${ }^{34}$ Russian wives were a notable exception, retaining property rights through marriage, although interestingly their business participation levels were not correspondingly higher. This is perhaps because wider business communities the world over tacitly accepted the creative solutions that by-passed the official letter of the law-with married women able to trade and secure credit for exampleand businesswomen therefore remained ubiquitous. Melanie Buddle's chapter highlights the way in which marriage and business were by no means mutually exclusive in British Columbia, with that society offering particular opportunities for female entrepreneurship, while Vanessa Oliveira describes the strategies used by Luso-Angolan women to protect their hard-earned profits from new husbands. It is important to remember that a single-income family was (and remains) economically impossible for the majority of the population; women had to work and business ownership could offer more flexibility than employment. It was therefore arguably in the best interests of the community to ignore activities that did not meet the exact letter of the law.

Our contributors also show that business was something in which respectable women might engage, particularly when it was framed as necessary or as a means to further the family's fortunes. Class mattered in many places, influencing the types of businesses and level of engagement, but a successful businesswoman was generally respected, except, perhaps, by a narrow elite. Having moved beyond the separate spheres theory,

\footnotetext{
${ }^{34}$ Aston and Di Martino, 'Risk, Success, and Failure'.
} 
historians have become more interested in intersections and liminal spaces, such as what sociologist Lyn Loflund called the 'parochial realm', arenas in which women were able to act relatively unhindered. As historian Clare Hoare has shown in the case of turn-of-the-century British shop-keeping women, many conducted their businesses among friends and neighbours, reaching beyond the domestic but still not far from home. ${ }^{35}$

Men did not (and often still do not) have the 'double bind' of reproductive, caring and domestic responsibilities faced by their female counterparts, for whom running a business from home was often one of the few money-making options available. This is, however, where region, class and economic conditions become so important. Some historians argue that industrialisation and the subsequent separation of workplace and home exacerbated women's withdrawal from the public sphere because the separate premises meant that they were no longer able to combine motherhood with working in the family firm. ${ }^{36}$ Elsewhere, it is suggested that small home-based businesses persisted through the nineteenth century, something that would enable childcare and business to exist side by side. ${ }^{37}$ While for many home and business premises were one and the same, their attention still had to be divided between commercial and domestic, ultimately limiting the size of the business itself. The co-location of work and home, too, was not universal, and Ulianova and Craig argue that many businesswomen were able to outsource their domestic duties to other women in much the same way as unmarried or wealthier businessmen would have done. ${ }^{38}$ Similarly, Alison C. Kay has argued that by assigning childcare and domestic duties to residential servants, businesswomen in London could maximise their earning potential. ${ }^{39}$

Like men, women could enter the business world through an informal apprenticeship in a family firm, a formal trade apprenticeship, the

${ }^{35}$ Lyn Lofland, The Public Realm: Exploring the City's Quintessential Social Territory, (Hawthorne, New York: Aldine de Gruyter, 1998), pp. 10-14; Clare Hoare, 'Making Provision: Female Grocery-Shop Proprietors in late-Victorian/Edwardian London', seminar paper, Women's History Network, Institute of Historical Research, King's College, London, 15 March 2019.

${ }^{36}$ Pinchbeck, Women Workers.

${ }^{37}$ Aston and Di Martino, 'Risk, success, and failure'; Kay, Foundations; Lewis, Unexceptional Women.

${ }^{38}$ Ulianova, Chap. 4 in this volume; Béatrice Craig, Global Female Entrepreneurs Workshop, Northumbria University, 16 April 2019.

${ }^{39}$ Kay, Foundations, pp. 96-7. 
development of self-taught domestic skills or by purchasing an enterprise. Other options for making money, particularly enough money to support a family, were limited. Female employees were habitually paid less than men, and girls were often not educated to a level where they could enter the professions, which were in any case closed to them for much of the nineteenth century across much of the globe. Middle-class men and women had different opportunities and expectations: men of the middling sort were encouraged to think of a career whereas women were not. Most working-class women were always expected to work, but, like workingclass men, they lacked the financial wherewithal to access higher education. Business was therefore an attractive option. The case studies in the following pages demonstrate how women across the nineteenth century and across the world used their businesses to provide for themselves and their families, overcoming a lack of education and juggling the additional ball of domestic responsibilities, with varying degrees of financial success.

Debates continue, not least over the meaning of women's participation in business and the types of businesses they ran. ${ }^{40}$ Women across the world were active in an enormous variety of trades, including those we might traditionally think of as masculine or, at the very least, 'unfeminine'. Female dentists, bankers, butchers and pirates all appear in these pages. Nevertheless, a common theme throughout, almost regardless of geographical location, local economy or political structure, is the predominance of so-called feminine trades among businesswomen. Female business owners are most commonly found trading in the textile, retailing and service industries, but it would be an oversimplification to assume that this was a sign of their marginalisation and restriction to 'women's work'. We must ask questions about women's access to capital and whether a struggle

\footnotetext{
${ }^{40}$ Sometimes these debates are the result of variations across time and space. For instance, in this volume it is noticeable that Bishop (Chap. 7) finds widows playing active roles in midcentury Australasian businesses, in much the same way as Aston found in the UK and Craig (Chap. 5) in France, suggesting agency and entrepreneurship. The chapters by Susana Martínez-Rodríguez and Carmen María Hernández-Nicolás (Chap. 14) on Spain and Mary Louise Nagata (Chap. 11) on Japan, however, suggest that widows there were more likely to be playing more passive roles in larger family businesses. While Alison Kay suggested within the context of her work on nineteenth-century London businesswomen that the goals of entrepreneurship can be seen as different for men and women, partly due to the cultural, economic and legal barriers faced by women in business, Susan Ingalls Lewis (Chap. 10) in her work on Albany in New York State, along with Catherine Bishop and others, have reminded us that most men's businesses were of a similar size during this period. Similarly, work by Aston and Di Martino on the later period in the UK argues for fewer gendered differences in business sizes, motives, practices and success.
} 
to secure it meant women entered trades with low start-up costs and overheads/that could be fitted around childcare.$^{41}$ We must also ask how many businesswomen were simply desperate and lacking in the skills, education and opportunity to run anything more lucrative or high status. On the other hand, the predominance of women in certain trades could be evidence of women recognising a comparative advantage and exploiting their femininity to cater for a predominantly female market, or cornering niche businesses where they had expertise. For example, Edith Sparks argues that women running hostelries in the gold rush towns were quick to sense an opportunity to market 'a meal cooked by a woman' to hungry men living away from their families. ${ }^{42}$ Similarly, Stana Nenadic argues that women in late-eighteenth- and early-nineteenth-century Scotland were uniquely placed to capture the dressmaking market as female customers preferred to buy from women. ${ }^{43}$

There is sometimes a temptation to apologise for women who used 'feminine' skills or catered to female customers, as if their achievements in lowly service industries are somehow both predictable and less important than activity in more 'masculine' enterprises. Why do historians and the general public alike get so excited finding a female butcher or undertaker but less so by a milliner or midwife? Equally, why is there an enduring sense that somehow a male carpenter, butcher or factory owner is more productive, important and skilled than a female corset maker, fancy goods shop proprietor or boarding housekeeper? All of these businesses contribute in different but equally important ways to the economic prosperity and broader society. Jennifer Aston and Wendy Gamber have argued that many of these 'feminine' and 'masculine' trades both required the same business skill sets, for instance securing a business premises and capital, learning how to make a product and completing business accounts. ${ }^{44} \mathrm{We}$

\footnotetext{
${ }^{41}$ Some early exploratory work on this topic in nineteenth-century Britain suggests that, unlike bankruptcy law where male and female traders were (mostly) treated equally, women seeking capital from formal lending institutions such as banks were heavily biased against female lenders. See Jennifer Aston, 'Financing Female Enterprise: Businesswomen and Finance in London, 1880-1910', conference paper, Economic History Society Annual Conference, Royal Holloway, April 2017. In contrast, in mid-nineteenth-century New Zealand, where lending was in the hands of private individuals, anecdotal evidence suggests that at least women participated equally. See Catherine Bishop, Women Mean Business, p. 28.

${ }^{42}$ Sparks, Capital Intentions.

${ }^{43}$ Stana Nenadic, 'The Social Shaping of Business Behaviour in the Nineteenth-century Women's Garment Trades', Journal of Social History 31, no. 3 (Spring, 1998): pp. 625-645.

${ }^{44}$ Aston, Female Entrepreneurship; Gamber, The Female Economy.
} 
might say, therefore, that those women who identified the business opportunities in which they had a competitive advantage over men, for instance in dressmaking, midwifery and boarding housekeeping, were exemplifying entrepreneurship at its best. Examples of such women can be seen in Blake Singley's turn-of-the-century Australian cookbook writers and Melanie Buddle's frontier society hoteliers and boarding housekeepers in British Columbia. Similarly, while some historians point to women's work tending to be underpaid, others, such as Jennifer Aston and Béatrice Craig, highlight the potential for both economic success and the potential for women to corner high-end markets. ${ }^{45}$ Susan Ingalls Lewis's chapter also shows that many women in business in American towns operated at a level beyond that of mere 'penny capitalists'.

\section{Towards a Global Perspective}

No edited collection is ever complete. Not all European countries are represented here, primarily because our aim is to move beyond that area, which already has a rich literature. This is not true for many other continents. Despite our best efforts, we have no chapters from North Africa, none covering South East Asia and, perhaps particularly surprisingly, none from India. A simple reason for our failure to locate potential contributors in other countries may be language. As lamentably monolingual native English speakers, we participate in scholarly networks and conversations conducted primarily in English. It is a powerful commentary on the state of the discipline more broadly that the contributors in this volume, while researching disparate areas of the globe, are predominantly based in academic institutions in Europe, North America, or in former British settler colonies. There may be parallel literatures discussing female entrepreneurship in Mandarin, Thai or Arabic, but these scholars and their work are not participating in the current discussions taking place at the World Economic History Conference or American and Europe-based Business History symposiums. Finding a way of communicating across this linguistic divide is another sort of challenge facing any transnational history.

There may also be other reasons for the lack of immediately obvious scholarship. Is it that women in these areas were not participating in

\footnotetext{
${ }^{45}$ Aston, Female Entrepreneurship; Béatrice Craig, Female Enterprise Behind the Discursive Veil in Nineteenth-Century Northern France, (London: Palgrave Macmillan, 2017).
} 
business in the nineteenth century? If this was the case, then we need to ask why. Do we need to extend our definitions of business activity even further to account for different types of economies and societies and to include a greater variety of economic activities? Within this volume itself, it is clear that individual political, cultural and religious regimes produced different priorities and economic and social structures. Familial enterprise rather than individual entrepreneurship, for instance, was particularly important in Japan. In Turkey, it was social entrepreneurship that came to the fore, while the contrast between Dutch and English legal, social and economic frameworks is clear in the Cape Colony.

It is impossible to ignore Europe in any discussion of the nineteenthcentury world-competing empires shaped much of the globe both economically and legally, intersecting with local geographies and Indigenous peoples in myriad ways. Scholarship by historians such as Antoinette Burton illustrates that non-white women from colonised societies engaged with the 'motherland' and created agency in sometimes surprising ways. ${ }^{46}$ Similarly, Sylvia Van Kirk's exploration of the role of women in the Canadian fur trade, not only uncovered the 'many tender ties' that connected Indigenous women and foreign men, but also their engagement in the business of fur trading. ${ }^{47}$ As is apparent in several chapters, women, particularly women of minority or Indigenous groups, were sometimes able to exploit the fractures in imperial societies and economies, operating in the liminal spaces or 'borderlands' between authorities. This is particularly apparent in Alisha M. Cromwell's discussion of enslaved and elite women in the American South, in C. Nathan Kwan's examination of Chinese women engaged in piracy and in Marie Francois' exploration of Mexican laundresses who benefited from the absence of regulation. Similarly, the business activities of Māori women in New Zealand and African female farmers in the Eastern Cape straddled two cultures, drawing upon personal relationships to establish trade with both communities.

We should not forget too, that despite any legal or cultural restrictions, European settler women occupied particular and privileged positions in colonial societies. There is an argument that women were hidebound by

\footnotetext{
${ }^{46}$ See, for example, Adele Perry, On the Edge of Empire; Gender, Race and the Making of British Columbia, 1849-1871, (Toronto: University of Toronto Press, 2001), Chapter 7; Antoinette Burton, At the Heart of the Empire: Indians and the Colonial Encounter in LateVictorian Britain, (Berkeley: University of California Press, 1998).

${ }^{47}$ Van Kirk, Many Tender Ties.
} 
the constraints of their whiteness, having to perform the ideals of European femininity in a foreign context more vigorously than they might have in Europe.$^{48}$ Yet it is also true that their relative power and status could give them more confidence in business, and the 'newness' of the colonial settlements may have provided economic opportunities they might not have had back 'home'. The privilege that could be enjoyed by white women is particularly pronounced in areas like the southern United States where, as Alisha M. Cromwell illustrates, the enslavement of people, even on a relatively small scale, could provide a highly profitable source of income. Equally, it should be noted that many 'independent' women in Britain owed their financial security and success to investments in slave plantations. ${ }^{49}$

This volume's omissions highlight specific places, times and communities for future research, pose questions about reasons for the gaps and challenge historians of both gender and business to think more broadly about their research. The research presented here continues to challenge the historiographic concept that domesticity dominated the lives of nineteenth-century women and that they had to balance social propriety with limited, feminine business opportunities. Much more importantly, however, the chapters in this volume identify areas of international common interest, moving beyond established geographical and periodisation frameworks by highlighting multiple interpretations of female entrepreneurship, considering everything from the daily minutiae of individual enterprises to the larger picture of national involvement over 60 years. Archives and sources better serve some countries than others, and each archive lends itself to different types of questions being asked. Thus, the chapters in this book take in not only broad timespans and widely varying geographies, but also use a multitude of methodological approaches and

\footnotetext{
${ }^{48}$ White women were expected to model appropriate female behaviour as exemplars of imperial womanhood. See Philippa Levine (ed.) Gender and Empire (Oxford: OUP, 2004), especially Barbara Bush, 'Gender and Empire: The Twentieth Century', p. 90.

${ }^{49}$ Hannah Young, 'Forgotten Women: Anna Eliza Elletson and Absentee Slave Ownership', in Katie Donnington, Ryan Hanley and Jessica Moody (eds), Britain's History and Memory of Transatlantic Slavery: Local Nuances of a 'National Sin', (Liverpool: Liverpool University Press, 2016): pp. 83-101; Jennifer Aston, 'More than just a Caretaker: Women's Role in the Intergenerational Transfer of Real and Personal Property in Nineteenth-Century Urban England, 1840-1900', in Amanda Capern, Briony McDonagh and Jennifer Aston (eds), Women and the Land, 1500-1900, (Woodbridge: Boydell and Brewer, 2019): pp. 244-66.
} 
source material. This demonstrates the richness of this field of enquiry and the variety of both experiences and interpretations.

Chapters range across the long nineteenth century and include microhistories, big data analysis and everything in-between. Some investigate small businesses, while others analyse larger companies; some focus on widows and unmarried women, others on wives. The chapters are organised chronologically, although there is considerable overlap, highlighting the comparisons and contrasts between countries and continents. The volume represents an important opportunity to weave together the threads of several fields of research and expand our historic understanding of female entrepreneurship, not just in urban Western societies, but globally, taking in differing legal, economic and political structures. The historians who have contributed to this volume range from Emeritus Professors to $\mathrm{PhD}$ students, and come from different academic backgrounds, in business as well as history. All are border-crossers, seeking to work collaboratively, imaginatively and, through the lens of female entrepreneurship in the long nineteenth century, to contribute towards a global history that includes all people and multiple perspectives.

\section{BIBLIOGRAPHY}

Ågren, Maria, 'Making Her Turn Around: the Verb-Oriented Method, the TwoSupporter Model, and the Focus on Practice', Early Modern Women: An Interdisciplinary Journal 13, no. 1 (2018): pp. 144-152

Alford, Katrina, Production or Reproduction?: An Economic History of Women in Australia, 1788-1850, (Melbourne: Oxford University Press, 1984)

Aston, Jennifer and Paolo Di Martino, 'Risk, success, and failure: female entrepreneurship in late Victorian and Edwardian England', Economic History Review 70, no. 3 (August 2013): pp. 837-58

Aston, Jennifer, 'Financing Female Enterprise: Businesswomen and Finance in London, 1880-1910', conference paper at Economic History Society Annual Conference, Royal Holloway, April 2017

Aston, Jennifer, 'More than just a Caretaker: Women's Role in the Intergenerational Transfer of Real and Personal Property in Nineteenth-Century Urban England, 1840-1900', in Amanda Capern, Briony McDonagh and Jennifer Aston (eds), Women and the Land, 1500-1900, (Woodbridge: Boydell and Brewer, 2019): pp. 244-66

Aston, Jennifer, Female Entrepreneurship in Nineteenth Century England: Engagement in the Urban Economy, (London: Palgrave Macmillan, 2016) 
Bandauer-Schöffmann, Irene, 'Businesswomen in Austria', in Beachy, Craig and Owens (eds), Women, Business and Finance in Nineteenth Century Europe, Rethinking Separate Spheres, (London: Berg, 2006)

Barker, Hannah, The Business of Women: Female Enterprise and Urban Development in Northern England 1760-1830, (Oxford: Oxford University Press, 2005)

Baskerville, Peter, "She Has Already Hinted at Board": Enterprising Urban Women in British Columbia 1863-1896', Histoire sociale-Social History 26, No. 52 (1993): pp. 205-227

Baskerville, Peter, A Silent Revolution?: Gender and Wealth in English Canada, 1860-1930,(Montreal, McGill-Queen's University Press, 2008)

Benton, Gregor, Hong Liu and Huimei Zhang (eds), Qiaopi Trade and Transnational Networks in the Chinese Diaspora, (Abingdon: Routledge, 2018)

Bishop, Catherine, Women Mean Business: Colonial Businesswomen in New Zealand, (Dunedin: Otago University Press, 2019)

Bishop, Catherine, 'The Serendipity of Connectivity: Piecing Together Women's Lives in the Digital Archive', Women's History Review 26, no. 5 (2017): pp. 766-780

Bishop, Catherine, 'Women on the Move: Gender, Money-making and Mobility in Mid-Nineteenth Century Australasia', History Australia 11, no. 2 (2014): pp. 38-59

Bishop, Catherine, Minding Her Own Business: Colonial Businesswomen in Sydney, (Sydney: NewSouth, 2015)

Bradbury, Bettina, From Wife to Widow: Lives, Laws and Politics in NineteenthCentury Montreal, (Vancouver: University of British Columbia Press, 2011)

Buddle, Melanie, The Business Of Women: Marriage, Family and Entrepreneurship in British Columbia 1901-51 (Vancouver: University of British Columbia Press, 2011)

Burton, Antoinette, At the Heart of the Empire: Indians and the Colonial Encounter in Late-Victorian Britain, (Berkeley: University of California Press, 1998)

Byrne, Paula J., 'Economy and Free Women in Colonial New South Wales', Australian Feminist Studies 11, no. 23 (1996): pp. 89-97

Candido, Mariana, 'Aguida Gonçalves da Silva, une dona à Benguela à la fin du XVIIIe siécle', Brésil(s): Sciences humaines et sociales 1, (2012): pp. 33-54

Candido, Mariana, 'Strategies for Social Mobility: Liaisons between Foreign Men and Slave Women in Benguela, c. 1770-1850', in Gwyn Campbell and Elizabeth Elbourne (eds), Sex, Power and Slavery: The Dynamics of Carnal Relations under Enslavement, (Athens: Ohio University Press, 2014): pp. 272-288

Carlin, Joe, A Brief History of Entrepreneurship: The Pioneers, Profiteers and Racketeers Who Shaped Our World, (New York: Columbia University Press, 2016)

Casson, Mark, 'Entrepreneurship': www.econlib.org/library/Encl/Entrepreneurship. html 
Choi, Chi Cheung, 'Kinship and Business: paternal and maternal kin in the Chaozhou Chinese family firms', Business History 40, (1998): pp. 26-49

Cott, Nancy, The Bonds of Womanhood: Women's Sphere in New England, 1780-1835, (New Haven: Yale University Press, 1977)

Craig, Béatrice and Alastair Owens (eds), Women, Business, and Finance in Nineteenth-Century Europe: Rethinking Separate Spheres, (Oxford: Berg 2006)

Craig, Béatrice, Female Enterprise Behind the Discursive Veil in Nineteenth-Century Northern France, (London: Palgrave Macmillan, 2017)

Craig, Béatrice, Women and Business since 1500: Invisible Presences in Europe and North America?, (NY: Palgrave Macmillan, 2016)

Curli, Barbara, 'Women Entrepreneurs and Italian Industrialization: Conjectures and Avenues for Research', Enterprise and Society 3, (2002): pp. 634-656

Dalziel, Raewyn, 'The Colonial Helpmeet: Women's Role and the Vote in Nineteenth-Century New Zealand', New Zealand Journal of History 11, (1977): pp. 112-23

Davidoff, Leonore and Catherine Hall, Family Fortunes: Men and Women of the English Middle Class, 1780-1850, Rev. ed. (London: New York: Routledge, 2002)

Ericsson, Tom, Women, family, and small business in late nineteenth century Sweden', The History of the Family 6, no. 2 (2001): pp. 225-239

European Commission, 'Report on Equality between Women and Men in the EU', https://ec.europa.eu/newsroom/just/document.cfm?doc_id=50074

Farrell, Rita, 'Women and Citizenship in Colonial Australia', in Patricia Crawford and Philippa Maddern (eds), Women as Australian Citizens: Underlying Histories, (Melbourne: Melbourne University Press, 2001): Chapter 5

Fong, Natalie, "Chinese Capitalists" and the Cultivation of Trade: AustralianChinese Transnational Businesses and Practices, 1880s-1940s', conference paper, Australian Historical Association conference 2019

Foote, Nicola, 'Rethinking Race, Gender and Citizenship: Black West Indian Women on the Atlantic Coast of Costa Rica, c.1920-1940', Bulletin of Latin American Research 23, no. 2 (April 2004), pp.198-212

Francois, Marie, A Culture of Everyday Credit, Housekeeping, Pawnbroking and Governance in Mexico City, 1750-1920, (Lincoln: University of Nebraska Press, 2006)

Gamber, Wendy, 'A Gendered Enterprise: Placing Nineteenth-Century Businesswomen in History', Business History Review 72, (Summer 1998): pp. 188-217

Gamber, Wendy, The Boarding House in Nineteenth-Century America, (Baltimore: Johns Hopkins University Press, 2007)

Gamber, Wendy, The Female Economy: The Millinery and Dressmaking Trades, 1860-1930, (Urbana: University of Illinois Press, 1997)

Gordon, Eleanor and Gwyneth Nair, 'The Economic Role of Middle-Class Women in Victorian Glasgow', Women's History Review 9, no. 4 (2000): pp. 791-814 
Green, David and Alistair Owens, 'Gentlewomanly Capitalism? Spinsters, Widows, and Wealth Holding in England and Wales C. 1800-1860', Economic History Review 3 (2003): pp. 510-36

Green, David, Alistair Owens, Josephine Maltby and Janette Rutterford (eds), Men, Women and Money, Perspectives on Gender, Wealth and Investment 1850-1930, (Oxford: OUP, 2011

Harris, Beth (ed.), Famine and Fashion: Needlewomen in the Nineteenth Century, (Aldershot and Burlington: Ashgate, 2005)

Hoare, Clare, 'Making Provision: Female Grocery-Shop Proprietors in lateVictorian/Edwardian London', seminar paper, Women's History Network, Institute of Historical Research, King's College, London, 15 March 2019

Humphries, Jane, "“Lurking in the Wings...": Women in the Historiography of the Industrial Revolution', Business and Economic History 20, (1991): pp. 32-44

Hunt, Margaret, The Middling Sort: Commerce, Gender, and the Family in England, 1680-1780, (Berkeley: University of California Press, 1996)

Hunter, Ian, Age of Enterprise: Rediscovering the New Zealand Entrepreneur 1880-1910, (Auckland, Auckland University Press, 2007)

Kay, Alison C., The Foundations of Female Entrepreneurship: Enterprise, Home and Household in London, c. 1800-1870, (London: Routledge, 2009)

Kingston, Beverley, A History of New South Wales, (Cambridge: Cambridge University Press, 2006)

Kingston, Beverley, My Wife, My Daughter and Poor Mary Ann: Women and Work in Australia, (Melbourne, Thomas Nelson, 1975)

Knight, Frank H., Risk Uncertainty and Profit (Boston and New York: Houghton Mifflen, 1921)

Kwolek-Folland, Angel, Engendering Business: Men and Women in the Corporate Office 1870-1930, (Baltimore: John Hopkins University Press, 1994)

Kwolek-Folland, Angel, Incorporating Women: A History of Women and Business in the United States, (NY: Palgrave Macmillan, 1998)

Lake, Marilyn, 'Rewriting Australia: Rewriting Women', Island, 68: pp. 96-104

Laurence, Anne, Josephine Maltby and Janette Rutterford (eds), Women and their Money 1700-1950: Essays on Women and Finance, (Abingdon: Routledge, 2009)

Levine, Philippa (ed.) Gender and Empire, (Oxford: OUP, 2004)

Lewis, Susan Ingalls, 'Female Entrepreneurs in Albany, 1840-1885', Business and Economic History 21, (1992): pp. 65-73

Lewis, Susan Ingalls, Unexceptional Women: Female Proprietors in mid-19th Century Albany New York 1830-1885, (Columbus: Ohio State UP, 2009)

Lofland, Lyn, The Public Realm: Exploring the City's Quintessential Social Territory, (Hawthorne, New York: Aldine de Gruyter, 1998)

Matthews, Jill Julius, 'Deconstructing the Masculine Universe: The Case of Women's Work', in Women and Labour Publications Collective (ed.), All Her Labours One: Working It Out, (Sydney: Hale and Iremonger, 1984): pp. 11-23 
Matthews, Jill Julius, 'Feminist History', Labour History 50, (May 1986): pp. 147-53

McDonagh, Briony, Elite Women and the Agricultural Landscape, 1700-1830 (Abingdon: Routledge, 2017)

Moring, Beatrice and Richard Wall, Widows in European Economy and Society 1600-1920, (London: Boydell, 2017)

Murphy, Lucy E., 'Business Ladies: Midwestern Women and Enterprise, 1850-1880', Journal of Women's History 3, no. 1 (1991): pp. 65-89

Nenadic, Stana, 'The Social Shaping of Business Behaviour in the Nineteenthcentury Women's Garment Trades', Journal of Social History 31, no. 3 (Spring, 1998): pp. 625-645

Oliveira, Vanessa S., 'The Gendered Dimension of Trade: Female Traders in Nineteenth Century Luanda', Portuguese Studies Review 23, no. 2 (2015): pp. 93-121

Palazzi, Maura, 'Economic Autonomy and Male Authority: Female Merchants in Modern Italy', Journal of Modern Italian Studies 7, (2002): pp. 17-36

Pantoja, Selma, 'Women's Work in the Fairs and Markets of Luanda', in Clara Sarmento (ed.), Women in the Portuguese Colonial Empire: The Theatre of Shadows, (Newcastle upon Tyne: Cambridge Scholars Publishing, 2008): pp. 81-94

Perry, Adele, On the Edge of Empire; Gender, Race and the Making of British Columbia, 1849-1871, (Toronto: University of Toronto Press, 2001)

Phillips, Nicola, Women in Business, 1700-1850, (Woodbridge: Boydell and Brewer, 2006)

Pinchbeck, Ivy, Women Workers and the Industrial Revolution, 1750-1850, 3rd ed. (London: Virago, 1981)

Purvis, Jane (ed.), Women's History: Britain 1850-1945, An Introduction, (Routledge: London, 2002 edn)

Rendall, Jane, Women in an Industrializing Society: England 1750-1880, (Blackwell: Oxford, 1990)

Roberts, Evan, 'Her Real Sphere? Married Women's Labor Force Participation in the United States, 1860-1940', (PhD thesis, University of Minnesota, 2007)

Rome, Adam Ward, 'American Farmers as Entrepreneurs, 1870-1900', Agricultural History 56, no. 1 (1982): pp. 37-49

Russell, Penny, A Wish of Distinction: Colonial Gentility and Femininity, (Melbourne, Melbourne University Press, 1994)

Schumpeter, Joseph A., Capitalism, Socialism and Democracy, (London: George Allen and Unwin, 1976)

Scott, Joan W., 'Gender: A Useful Category of Historical Analysis', The American Historical Review 91, no. 5 (Dec. 1986): pp. 1053-75

Sharpe, Pamela, The Nineteenth Century Businesswoman in the British Isles: Work Culture, Adaptation and the Lace Trade, (Nedlands, W.A.: Centre for Women 
and Business, Graduate School of Management, University of Western Australia, 2003)

Simonton, Deborah and Anne Montenach (eds), Female Agency in the Urban Economy: Gender in European Towns, 1640-1830, (New York: Routledge, 2013) Sinn, Elizabeth, 'Women at Work: Chinese Brothel Keepers in 19th Century Hong Kong', The Journal of Women's History 19, no. 3 (2007): pp. 87-111

Smith, Bonnie, Ladies of the Leisure Class, The Bourgeoisie of Northern France in the Nineteenth Century, (Princeton: Princeton University Press, 1981)

Sparks, Edith, 'Married Women and Economic Choice: Explaining Why Women Started Businesses in San Francisco between 1890 and 1930', Business and Economic History 28, no. 2 (Winter 1999): pp. 287-300

Sparks, Edith, Capital Intentions: Female Proprietors in San Francisco, (Chapel Hill: University of North Carolina Press, 2006)

Steinbach, Susie, Women in England 1760-1914: A Social History, (Weidenfeld and Nicolson: London, 2004)

Strachan, Glenda and Lindy Henderson, 'Assumed but Rarely Documented: Women's Entrepreneurial Activities in Late Nineteenth Century Australia', Paper presented at the 'The Past is Before Us' conference, Sydney 2005

Strachan, Glenda and Lindy Henderson, 'Surviving Widowhood: Life Alone in Rural Australia in the Second Half of the Nineteenth Century', Continnity and Change 23, no. 3 (2008): pp. 487-508

Ulianova, Galina, Female Entrepreneurs in Nineteenth-Century Russia, (London: Taylor and Francis, 2009)

Van Kirk, Sylvia, Many Tender Ties: Women in Fur-Trade Society, 1670-1870, (University of Oklahoma Press, 1983)

Vickery, Amanda, 'Golden Age to Separate Spheres? A Review of the Categories and Chronology of English Women in History', The Historical Journal 36, no. 2, (June 1993): pp. 383-414

Wheeler, Douglas L., 'An Angolan Woman of Means: D. Ana Joaquina dos Santos e Silva, Mid-Nineteenth Century Luso-African Merchant-Capitalist of Luanda', Santa Bárbara Portuguese Studies 3, (1996): pp. 284-97

Whittle, Jane, 'Enterprising Widows and Active Wives: Women's Unpaid Work in the Household Economy of Early Modern England', History of the Family 19, no. 3 (2014): pp. 283-300

Wright, Claire, Beyond the Ladies Lounge: Australia's Female Publicans, (Melbourne: Melbourne University Press, 2003)

Yeager, Mary A. (ed.), Women in Business, 3 vols, (Cheltenham: Edward Elgar Publishing; 1999)

Yeager, Mary, 'Making a Difference: Women and Business History', (review of Angel Kwolek-Folland, Incorporating Women: A History of Women and Business in the United States, (NY: Twayne Publishers, 1998)), April 1999, https:// networks.h-net.org/node/24846/reviews/25631/yeager-kwolek-follandincorporating-women-history-women-and-business 
Yeager, Mary, 'Reframing Business Realities: A Look back into the Future of American Business History', Travail, Genre et Sociétés 1, no. 3 (2005): pp. 95-113

Young, Brian, 'Getting around Legal Incapacity: The Legal Status of Married Women in Trade in Mid-Nineteenth-Century Lower Canada' in Peter Baskerville (ed.), Canadian Papers in Business History, (Victoria, British Columbia: Public History Group University of Victoria, 1989), pp. 1-16

Young, Hannah, 'Forgotten Women: Anna Eliza Elletson and Absentee Slave Ownership', in Katie Donnington, Ryan Hanley and Jessica Moody (eds), Britain's History and Memory of Transatlantic Slavery: Local Nuances of a 'National Sin', (Liverpool: Liverpool University Press, 2016): pp. 83-101

Zimmerman, Kari, "As Pertaining to the Female Sex": The Legal and Social Norms of Female Entrepreneurship in Nineteenth-Century Rio de Janeiro, Brazil', Hispanic American Historical Review 96, no. 1 (2016): pp. 39-72

Open Access This chapter is licensed under the terms of the Creative Commons Attribution 4.0 International License (http://creativecommons.org/licenses/ by $/ 4.0 /$ ), which permits use, sharing, adaptation, distribution and reproduction in any medium or format, as long as you give appropriate credit to the original author(s) and the source, provide a link to the Creative Commons licence and indicate if changes were made.

The images or other third party material in this chapter are included in the chapter's Creative Commons licence, unless indicated otherwise in a credit line to the material. If material is not included in the chapter's Creative Commons licence and your intended use is not permitted by statutory regulation or exceeds the permitted use, you will need to obtain permission directly from the copyright holder.

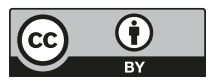

